\title{
ЦИТ: ua117-071
}

DOI: 10.21893/2415-7538.2016-05-1-071

УДК 622.276

\section{АНАЛІЗ ПРОГНОЗУВАННЯ ВИДОБУТКУ НАФТИ 3 ВИКОРИСТАННЯМ ХАРАКТЕРИСТИК ВИТІСНЕННЯ}

Івано-Франківський начуінальний технічний університет нафти і газу

Україна,76019, Івано-Франківськ, Карпатська 15,

\section{ANALYSIS PRODUCTION FORECASTING OF OIL USING "DISPLACEMENT-CHARACTERISTICS" \\ Ivano-Frankivsk national technical university of oil and gas, Ukraine, 76019, Ivano-Frankivsk, Karpatska15}

Анотація. Сьогодні розробка нафтових родовищ, оптимізація і оцінювання експлуатаиії потребує універсальних методів та моделей. Вони повинні виконувати прогноз видобутку нафти швидко i точно. Більшість з них потребує комплексу припущень $і$ включають важкі математичні обрахунки. Тому існує проблема в розроблянні таких моделей, які б працювали безвідмовно з мінімальним часом обрахунку даних

Дана стаття показує використання моделей та ілюструє реальний прогноз видобутку.

Ключові слова: прогнозування, характеристики витіснення, аналітичні моделі.

Abstract. Nowadays reservoir of oil fields, optimization and assessment of exploitation requires multiple methods and models. They should generate forecasts of oil production fast and reliable. Most of them need a lot of complex simulations and include difficult mathematic operations. There is the problem developing such models that work immediately without spending hours by doing forecast.

This paper states about using such models and illustrates the real forecast.

Key words: forecasts of oil production, displacement characteristics, production curves, analytical models, reservoir engineering.

Для прийняття об'єктивного рішення щодо подальшої розробки необхідно досконало володіти методами оперативного аналізу та вмінням правильно інтерпретувати отримані результати. На сьогоднішній день найбільш точними методами $\epsilon$ методи математичного моделювання, які базуються на характеристиках витіснення. Нижче розглядаються методики оцінки дренованих запасів та прогнозування видобутку нафти за падінням дебіту в часі. Слід зауважити, що “правдивість” прогнозу за характеристика витіснення допустима лише на пізніх стадіях розробки, коли у пласт закачується велика кількість води і обводненість продукції досягає великих значень.

Під характеристиками витіснення розуміють залежності між накопиченими видобутком нафти $\mathrm{Q}_{\mathrm{H}}$, рідини $\mathrm{Q}_{\mathrm{p}}$, води $\mathrm{Q}_{\mathrm{B}}$, накопиченими об'ємами запомповуваної води $\mathrm{Q}_{3}$. Вони застосовуються при аналізі показників розробки на водонапірних режимах. Найбільш часто використовуються, 
запропоновані Б.Ф. Сазоновим, А.А. Казаковим, С.Н. Назаровим. Показники тісно корелюються між собою, що дає ілюзію їх можливостей для якісного прогнозування. Однак, слід зауважити, що високі коефіцієнти кореляції $\epsilon$ наслідком опосередненого зв'язку з часом.

Характеристики витіснення базуються на тому, що на пізніх стадіях розробки покладу зв'язок між накопиченими видобутками в різних координатах має лінійний характер і відповідно можуть бути представлені у вигляді :

Характеристика

Б.Ф. Сазонова

А.А. Казакова

С.Н. Назарова
Формула

$Q_{\mathrm{H}}(t)=a+b \cdot \ln Q_{\mathrm{p}}(t)$

$Q_{\mathrm{H}}(t)=a+b \cdot \frac{1}{Q_{\mathrm{p}}(t)}$

$\frac{Q_{\mathrm{p}}(t)}{Q_{\mathrm{H}}(t)}=a+b \cdot Q_{\mathrm{B}}(t)$

Нижче розглядається методика прогнозування видобутку нафти за характеристика витіснення на прикладі Луквинського нафтового родовища (поклад МЛ-2):



Рис. 1. - Фактична зміна видобутку в часі

Згідно вимог обирається останній спадний період, по якому виконується прогнозування не більше як на $1 / 3$ від величини даного періоду.

Методика побудови моделі полягає у наступних етапах :

1. Розрахунок накопиченого видобутку по даному періоду ;

2. Обрання запропонованої характеристики витіснення ;

3. Визначення коефіцієнтів $a$ і $b$ шляхом оброблення фактичних даних ;

4. За характеристикою витіснення розраховуємо теоретичні значення видобутку нафти, будуємо графічну залежність.

5. Знаходимо середньоквадратичні відхилення та коефіцієнт кореляції. 
Коефіцієнт кореляції - показник, який використовують для вимірювання щільності зв'язку між результативними і факторними ознаками у кореляційнорегресійній моделі за лінійної залежності. За абсолютною величиною коефіцієнту кореляції коливається в межах від -1 до +1 . Чим ближчий цей показник до 0, тим менший зв'язок, а чим ближчий він до \pm 1 , тим зв'язок тісніший. Знак «плюс» при коефіцієнті кореляції означає прямий зв'язок між ознаками х і у, знак «мінус» - обернений.

Отримані наступні результати прогнозу видобутку нафти за характеристиками витіснення:

1. Г.С. Комбарова $-\mathrm{r}=-0.99889$

2. Б.Ф. Сазонова $-\mathrm{r}=0.999877$

3. А.М. Пірвердяна $-\mathrm{r}=-0.999762$

4. С.Н.Назарова і Н.В.Сипачева $-\mathrm{r}=0.99968$

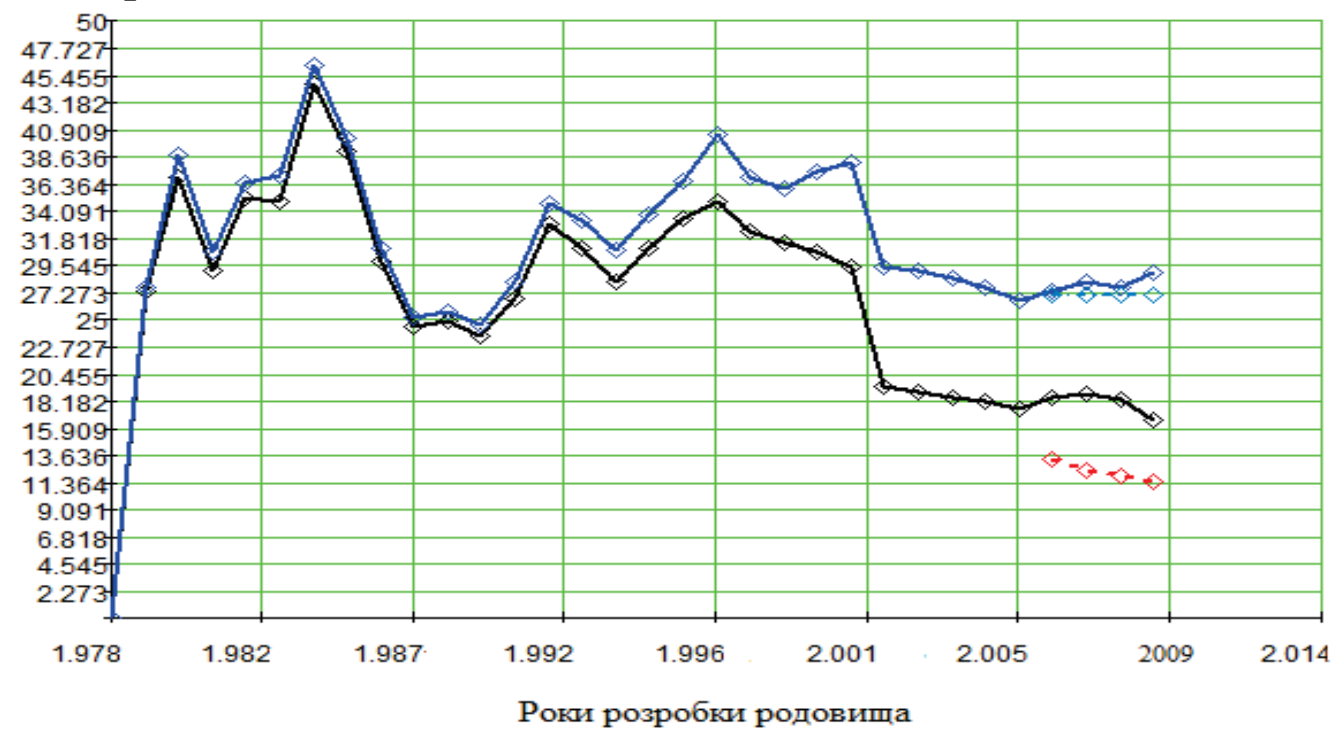

Рис 2. - Прогнозування за характеристикою витіснення А.М. Пірвердяна.

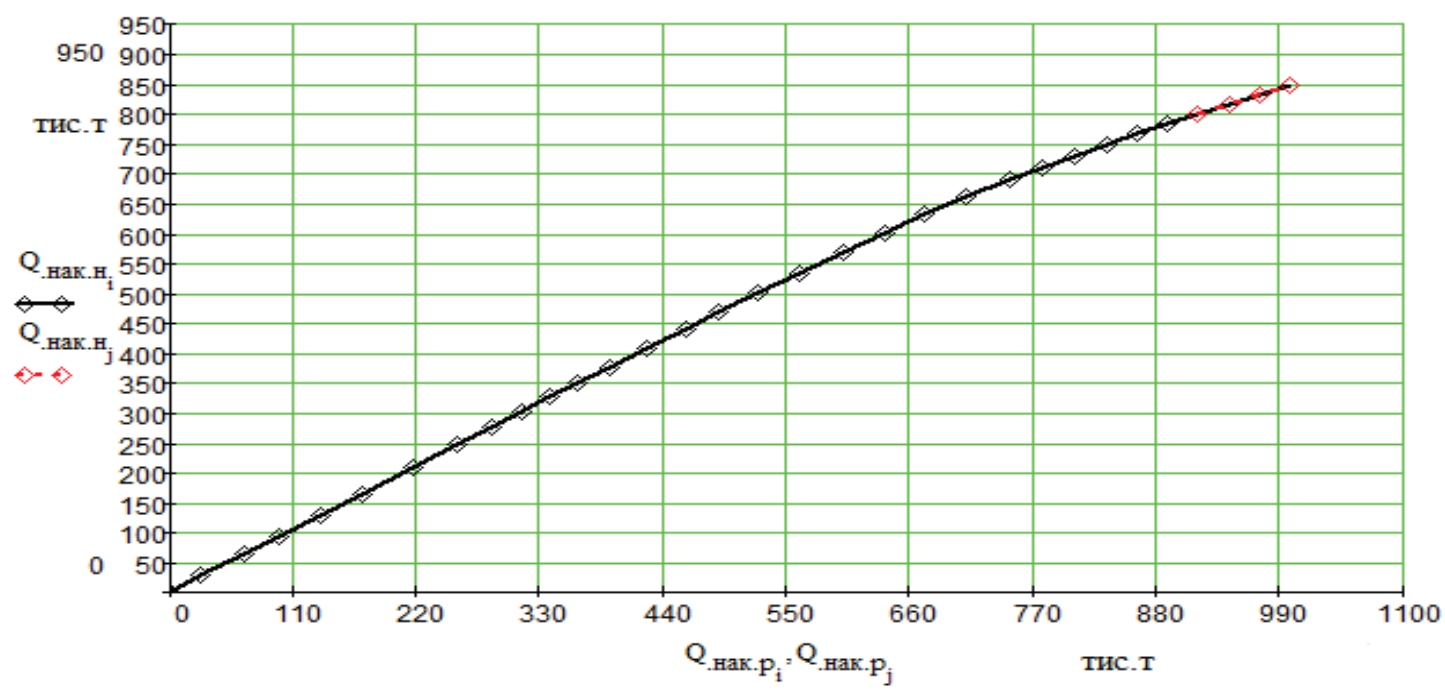

Рис. 3. - Залежність фактичного і розрахованого накопиченого дебіту нафти від фактичного і розрахованого накопиченого дебіту рідини.

Даний розрахунок проводився на основі фактичних даних розробки 
Луквинського нафтового родовища 31978 по 2008 рік. Для аналізу було вибрано дані по 2004 рік включно, а прогноз виконувався на наступні 4 роки, тобто на 2005, 2006, 2007 і 2008 роки.

Суть полягала в тому, щоб порівняти фактичні і розраховані результати, таким чином підтвердити або спростувати твердження стосовно доцільності використання даних методик. На рис. 3 наведено дві лінії: чорна крива описує зв'язок між фактичними накопиченим дебітом нафти і накопиченим дебітом рідини, а червона - між розрахованими. На графіку чітко видно кореляцію фактичних і розрахованих показників розробки, що дозволяє використання описаної методики в промислових умовах.

На основі проведеного аналізу можна зробити висновок, що використання характеристик витіснення для прогнозування на пізніх стадіях розробки родовища дають достатньо точні для практичних цілей результати.

Література:

1. Акульшин А.И. Прогнозирование разработки нефтяных месторождений // М.: Недра, 1988, - 240с.: ил. ISBN - 5 - 247 - 00130 - 3.

2. Меркулова I.В. Графические методы анализа при добыче нефти // М.:Недра, 1986, - 125c.

3. Дейк Л.П. Основы разработки нефтяных и газовых месторождений // Перевод с английского - М.: ООО “Премиум инжениринг”, 2009 - 570 с., ил ISBN $978-5-903363-10-0$.

Науковий керівник : Драган I.M Статья отправлена: 1.04.2017 г. (C) Лукін О.А

ЦИТ: иа117-086

DOI: 10.21893/2415-7538.2016-05-1-086

УДК 622.276

ДОСЛІДЖЕННЯ ОСОБЛИВОСТЕЙ ПРОВЕДЕННЯ ПОІНТЕРВАЛЬНОГО ГІДРАВЛІЧНОГО РОЗРИВУ В ГОРИЗОНТАЛЬНИХ СВЕРДЛОВИНАХ

Івано-Франківський національний технічний університет нафти і газу, Івано-Франківськ, Карпатська 15, 76000

Busko B.M., Khudin M.V. RESEARCH OF FEATURES INTERVAL HYDRAULIC FRACTURING IN HORIZONTAL WELLS

Ivano-Frankivsk National Technical University of Oil and Gas, Ivano-Frankivsk, Karpatska 15, 76000

Анотація. У нафтовидобувній галузі зниження обсягів нафти головним чином пов'язане зі структурою порід-колекторів, більшість з яких становлять важковидобувні, енергетично-виснажені та високообводнені поклади, висока неоднорідність яких, призводить до нерівномірного вилучення нафти. Механічні методи впливу ефективні в твердих породах, коли створення 